\title{
Islamismen truer demokratiet
}

Chahdortt Djavann

\section{Islam kan leve uden det islamiske tørklæde; men islamismen kan ikke. Den er missionerende, anti- demokratisk og styret af mænd, hvis identitet er afhængig af kvindeundertrykkelse. Tørklædet er dens banner}

Jeg var tolv år, da det islamiske regime tog magten i Iran. I ti år bar jeg tørklæde, som det var påbudt for alle kvinder og alle piger ældre end seks år. Jeg fik islamisk undervisning i skolen og på universitetet. Jeg fik nok af taler af mullaher, der præsenterede alle de begrænsninger og ydmygelser, de påtvang hele befolkningen og især kvinderne (som skulle skjule deres kvindelighed), som hellige dogmer. Jeg tilhører således den generation af iranere, som oplevede, at deres land tippede over i religiøs - islamisk - fundamentalisme.

At vestlige regeringer støtter diktaturer og teokratier og konkurrerer om at indgå økonomiske aftaler med dem, er efterhånden kendt af alle, selv fattige analfabetiske kvinder i det indre Afghanistan. Men så forkert denne internationale praksis er, møder den stort set ingen modstand i noget demokratisk land. Den fortsætter bare. De vestlige demokratier tænker mere på deres økonomiske interesser end på befolkningernes frigørelse. I dag konfronteres vi, især i Europa, af islamister, hvis ordvalg, retorik og sofismer er de samme som dem, man serverede for os i 1979 i Iran, og som har kastet dette land i gabet på et totalitært og teokratisk regime.

Jeg har meget grundigt studeret det skolesystem, som blev indført efter 'den islamiske revolution', og den ideologi, som udbredes i de iranske skolebøger. Jeg har i detaljer analyseret spørgsmålet om tørklædetvangen.

Jeg har forsøgt at analysere, hvad det islamiske tørklæde er, dets sociologiske, antropologiske, psykiske og seksuelle betydning og de juridiske omstændigheder, der knyttes til islamisk retspleje. Hvert eneste ord jeg ytrer om dette emne udspringer af 
uudslettelige billeder og smertelige erindringer. Jeg skal behandle fire punkter, der selvfølgelig hænger nøje sammen:

1 Islamismens oprindelse og strategi. 2 Det islamiske slør eller tørklæde . dets betydning og antropologiske rækkevidde.

3 Det islamistiske system og tørklædet.

4 Sekularisme som en demokratisk værdi.

Men først bør jeg nok præcisere de begreber, jeg vil henvise til. Muslim: En person hvis religion er islam. Han kan være stærkt troende eller moderat, mere eller mindre praktiserende, ikke-praktiserende troende eller endog praktiserende muslim uden egentlig tro.

Islamist: En muslim for hvem Koranen er Guds sidste vilje og den mest fuldkomne af de hellige bøger og islam den bedste af de monoteistiske religioner. I hans øjne må kristne og jøder konvertere til islam for at rense sig, og islamiske dogmer må diktere det politiske, sociale og private liv i ethvert samfund.

Islamisk jihadist: En islamist for hvem tiden til at omvende vantro (kristne og jøder) er forbi, og tiden er inde til jihad, hellig krig mod de vantro. Jihadistisk terrorist: En islamist for hvem enhver handling er berettiget, hvis den dræber vantro.

Islamistisk system: Et system hvor islamiske dogmer styrer både den enkeltes privatliv og gruppens politiske og sociale liv.

\section{Islamismens oprindelse og strategi}

Islamismen som vi kender den i dag fandtes ikke for 25 år siden. Det er Vesten (USA og Europa, Storbritannien og Frankrig), som med sin kyniske politik i Mellemøsten (Afghanistan, Iran, Irak) har fremprovokeret den. Det er først og fremmest i Iran, at islamismens slagord, semantikker og strategier blev udviklet. De bruges i dag i Europa, under andre omstændigheder (ikke mindst fordi islam her er en minoritetsreligion), men med de samme udgangspunkter og formål (at udbrede islam over hele verden, men frem for alt at skabe eller styrke islamistiske regimer i Mellemøsten og i alle muslimske lande).

For 28 år siden udførte islamisterne et af deres første angreb i Iran. Flere end 300 mennesker omkom i en biograf som straf for at have valgt at se en film under ramadanen. De europæiske regeringer, som havde besluttet at følge USA's eksempel og tilskynde til shahens fald, forestillede sig måske, at militæret ville styre de religiøse elementer; men talrige vestlige intellektuelle og iranske intellektuelle i Vesten hengav sig til en forestilling om, at islam ville redde Iran fra shahens korruption.

Det var i Iran, de islamiske taktikker blev perfektioneret. De gik først og fremmest ud på at sætte lighedstegn mellem Iran og Palæstina. "Iran er blevet Palæstina. Det er tid til handling!" var slagordene, der 


\section{CHAHDORTT DJAVANN}

spredtes over hele landet. Det kunne forekomme underligt at sætte lighedstegn mellem de to (og mellem shahen og Israel); men det var den afgørende tændsats. Det var det religiøse element, som blev sat i front. Det var islam, der var i krig med Israel, og shahen havde som sin far 'ydmyget' islam ved at sætte hengivne muslimer i fængsel, men også ved at 'tvinge' kvinder til at lægge sløret og i almindelighed ved at følge forbilleder fra Vesten. En stor del af Irans befolkning var marginaliseret, vred og frustreret, og islamisterne kunne omsætte disse følelser til religiøs energi. De kunne spille på landbefolkningens følelse af ydmygelse, på social uretfærdighed, økonomisk ulighed og diskrimination. Overdreven religiøsitet, den evindelige påberåbelse af islam, vrede; men for islamisterne var denne vrede kun et middel til at nå et mål.

Den formørkelse, der har hersket i Iran i mere end et kvart århundrede, har kun forværret den økonomiske, sociale og kulturelle elendighed, som er knusende for en stor del af befolkningen. For de øvrige går uhæmmet kapitalisme og religiøst barbari smukt hånd i hånd. Mænd, kvinder og børn bliver ustandselig ydmyget, uanset hvor ubetydelige eller private ting de foretager sig, og de fattiges tilværelse er ikke blevet et hår bedre.

Religiøsitet bragt til yderligheder fører til, at etniske og nationale referencer erstattes af religiøse referen- cer. I krigen mellem Iran og Irak var fædrelandet islam, ikke Iran. Det var islam, de iranske soldater forsvarede. På de armbind som børn og unge bar, når de blev sendt ind over minefelter for at rydde vejen for de voksne soldater, stod ordet 'Islam' ikke 'Iran'. Det slagord, som Khomeini og hans mullaher hamrede hjem, var "Islam er i fare!" (som om irakerne ikke var muslimer og for det meste shiitter). Ikke en eneste gang i de otte år blev det sagt, at det var hjemlandet, den iranske befolkning eller friheden, som var i fare. Islam trådte i stedet for fædreland, familie og etik.

I løbet af krigens første år udryddede den islamiske regering sine modstandere. De blev fordømt som fjender af islam og henrettet. På den baggrund forstår man bedre betydningen af udtrykket 'islamofobi', som dukkede op i mullahernes Iran og rettede sig mod deres totalitære ide om, at religionskritik er racistisk. Men samtidig er al tale om islamofobi naturligvis også vand på islamisternes mølle

Islamistiske bevægelser er internationale. Det kan man observere alle de steder, hvor de griber til væbnet kamp: Afghanistan, Irak, Libanon, Palæstina, Israel..... Islamisterne interesserer sig ikke for indvandrernes vidt forskellige oprindelse. Som om de forskellige lande, de stammer fra, aldrig har eksisteret med deres forskellige traditioner, sprog, kultur og historie. Islamisterne, der optræder 
som talsmænd for retten til at være anderledes, anerkender ikke retten til at være forskellig inden for den såkaldt muslimske verden, og de forsøger at præsentere alverdens muslimer som en monolitisk blok.

Selvfølgelig er denne enhed kun et blændværk, og man ved jo godt, at både forskellighed og til tider total uenighed gør sig gældende, når det kommer til kontakt og handling. Men det er retorisk taktik til brug for immigranterne. Islam bliver den eneste referenceramme, pejlemærket, det fælles fædreland. Islamisterne taler om 'en ny muslimsk identitet', og i dette udtryk ligger deres projekts sande natur. Den ny muslimske identitet er en kampidentitet, som stort set er bygget på den israelsk-palæstinensiske konflikt, på at muslimske unge i deres ghettoer identificerer sig med intifadaens unge palæstinensiske helte. Denne identifikation er inspireret og konstrueret af islamismens missionærer.

Det er på denne måde lykkedes islamisterne at mobilisere et lille mindretal af den muslimske befolkning, mens det store flertal modstår islamismens lokketoner. I bund og grund kerer islamisterne sig lige så lidt i Europa som i de muslimske lande om de fattige og de arbejdsløse; men de udnytter de problemer, der opstår på arbejdsmarkedet, med 'ghettoisering', social udstødelse og racisme. Islam, som for 25 år siden blev fremstillet som Mellemøstens politiske og moralske redning, har nu ambitioner om at redde de muslimer, der lever i Vestens dekadente samfund.

Islamisternes strategi i Europa ligner den, de har benyttet sig af i de muslimske lande, nu bare med Vestens muslimske befolkninger som mål. Strategien er global; men den tilpasses forholdene i hvert enkelt land. Den benytter sig frem for alt af tvetungethed og ordkløveri. Modstandere af vestlig lov udtaler sig på lovens vegne. Man ved ikke, om man skal le eller græde, når man på gaden i et teokratisk land ser en flok tilslørede kvinder demonstrere for deres franske søstres frihed.

Denne karikerede efterabning af demokratiet er karakteristisk for en bevægelse, som ikke producerer tænkere og teoretikere, men retorikere og sofister. På marokkanske universiteter kan man i dag se skæggede unge mænd forklare, at den familielov, som det marokkanske parlament har vedtaget, er en krænkelse af kvindens frihed, og at man må have 'ret' til at vende tilbage til islams 'principper'. Man kan frem for alt genkende den islamistiske diskurs på dens idelige gentagelse af ordene 'frihed', 'ret' og 'demokrati' og på dens naivt perverse (eller perverst naive) brug af dem.

Der er i den islamistiske diskurs, $\mathrm{i}$ den islamistiske 'attitude', en grundlæggende tvetydighed eller uhæderlighed, som man føler eller opfatter uden præcist at kunne sætte fingeren på den. Den udfolder sig i virke- 


\section{CHAHDORTT DJAVANN}

ligheden på flere planer. For det første i ordforrådet. Ord hentet fra den demokratiske tradition bliver vendt på hovedet. Når der tales om 'frihed', skal det forstås som frihed til fuldkommen at adlyde forskrifterne $\mathrm{i}$ islam (eller en bestemt fortolkning heraf). Når der tales om 'ret', skal det forstås som retten til at udøve denne frihed til lydighed.

For det andet i sproget mere generelt. Der er fuldkommen tavshed om alt, der ville kunne mistænkes for at genere islamismen. Der refereres kun til demokratiet for at afvise de vestlige demokratiers dekadence, deres 'demokratiske underskud', hvor islam ikke får tilkendt passende plads. En konstatering der ikke ser ud til at berøre islamisterne, er at islam åbenbart kun har passende plads i udemokratiske stater, hvor den fylder det hele.

Påkaldelsen af Gud, 'Allah Akbar', 'Gud er Stor', har forskellige betydninger, fremstillinger og konsekvenser alt efter de omstændigheder, hvorunder den ytres. Enhver praktiserende muslim påkalder Gud flere gange daglig i sine bønner. Dette 'Allah Akbar' er udtryk for hans personlige tro.

Det 'Allah Akbar' som sendes ud over moskéernes højttalere, er en påmindelse til det muslimske samfund om at være sig selv bevidst. Dette 'Allah Akbar' er mere socialt og kollektivt end personligt. Endelig er der det sidste 'Allah Akbar', kampråbet som gjaldede i Irans byer for 28 år siden, og som man nu har kunnet høre i byerne i Europa. Det er et politisk 'Allah Akbar' på erobringstogt, som hævder, at Allahs love står over alle menneskets love. Det er et af det islamistiske systems våben, og det siger til muslimer $\mathrm{i}$ hele verden, at den islamistiske ideologi søger at trænge frem og erobre terræn, at islamisterne i Vesten slås for sagen, ude i felten.

\section{Tørklædets betydning}

Spørgsmålet om tørklædet er et spørgsmål for sig, som må klares af inden enhver debat om skolen og det sekulære samfund. Tørklædet er på ingen måde bare et religiøst symbol som det kors, piger eller drenge kan bære om halsen. Tørklædet, eller hijab, er ikke bare et tørklæde om hovedet. Det bør helst skjule kroppen fuldstændigt. Det betegner den radikale adskillelse mellem det kvindelige og det mandlige rum. Eller mere præcist: det definerer grænserne for det kvindelige rum. Tørklædet, hijab, er det mest barbariske islamiske dogme, som trænger sig ind på kvindens krop.

Hvad betyder det at give piger tørklæde på? Det betyder, at de gøres til sexualobjekter. Objekter, fordi tørklædet påtvinges dem og fra da af bliver en del af deres personlige og sociale eksistens. Sexualobjekter, ikke bare fordi det tilhyllede hår er et seksuelt symbol i dobbelt forstand (det skjulte fremhæves, og det for- 
budte vækker begær), men fordi tørklædet placerer barnet eller den unge pige på markedet for sex og ægteskab.

Konstruktionen af den kvindelige og mandlige identitet i islam hviler på kvindens hobj og haya og mandens nâmous og qeyrat. Disse betydningsladede ord er bærere af tunge traditioner og forbehold, som er passende for hvert køn, og som er blevet overført fra generation til generation. De betyder sådan noget som kvindens dyd og skam og mandens ære og ihærdighed.

Nâmous er mandens seksuelle ære. Enhver muslims personlige nâmous er tabu og må være skjult for andre mænd, for uvedkommende blikke. Dens garanter er moderen, søsteren, hustruen, datteren, den kvindelige krop. Tørklædet gemmer $n \hat{a}-$ mous, og han er dybt afhængig af det; for hans mandlige ære, essensen af hans identitet, gemmer sig under kvindens tørklæde. Qeyrat, ihærdighed, symboliserer den muslimske mands virilitet og evne til at opretholde sin nâmous, sin seksuelle ære, hvis objekt er den kvindelige krop, som derfor er tabu og ikke må udsættes for andre mænds utilbørlige blikke.

Kvindens hobj og haya, hendes dyd og skam, er garanterne og udtrykket for den muslimske mands ære og ihærdighed. Jo mere skamfuld og dydig en kvinde er, desto mere ære og ihærdighed tillægges hendes far, brødre og ægtemand. Enhver kon- takt med andre mænd, ethvert forsøg på tilnærmelse mellem de to $k ø n$, vanærer den muslimske mand. Det er ikke kun det seksuelle forhold, der er tabu; det andet køn, den kvindelige krop i sig selv er tabu. Derfor skal kvinden være tildækket, og derfor afhænger den muslimske mands ære og dermed hans identitet af tørklædet. Så måske afslører tørklædet frem for alt den muslimske mands usikkerhed, når hans liv og identitet er underkastet en stadig frygt for kvindelige fejltrin: en forvildet hårlok, en smule synlig hud. Den utilslørede kvinde kan ryste hele fundamentet for den mandlige identitet $\mathrm{i}$ islam.

En pige er garant for sin fars og sine brødres ære. Når hun er gift, solgt, forlader hun det faderlige opsyn og bliver garant for sin mands ære. I tilfælde af skilsmisse vender hun tilbage til sin faders opsyn, og han bliver endnu en gang afhængig af hendes dyd. En fraskilt kvinde i sin faders varetægt er en kilde til bekymring for sin far og sine brødre, en vare sendt retur.

Som nævnt placerer tørklædet den unge pige på markedet for sex og ægteskab. Hvad der i de vestlige lande betragtes som pædofili, er ikke kun ikke en forbrydelse i de muslimske lande, men bliver endog anbefalet af de islamiske love: en pige kan giftes fra hun er ni år, og fra da af skal hun bære tørklæde. Men det forholder sig faktisk sådan, at man i muslimske lande og funda- 


\section{CHAHDORTT DJAVANN}

mentalistiske kredse giver dem tørklæde på endnu tidligere; for i islamisternes øjne kan man ikke tidligt nok berøve småpigerne retten til deres eget liv. I Iran, i pigeskolerne hvor der ikke er ansat nogen mænd, og i klasser hvor lærerinden selv bærer tørklæde, må selv piger på syv år ikke tage tørklædet af.

En mindreårigs tørklæde er et overgreb mod hende. Det signalerer, at hun er kønsmoden og klar til at blive 'indtaget' seksuelt. Det indpoder også i hende bevidstheden om hendes køns og hendes sociale rettigheders mindreværd i forhold til drengene. Det er et fysisk, psykisk, socialt og seksuelt overgreb mod mindreårige at give dem tørklæde på. Og det er af hensyn til de mindreåriges beskyttelse og ligestilling uanset køn, farve, kultur eller religion, at mindreåriges tørklæde bør forbydes, og ikke kun i skolen.

\section{Det islamistiske system og tørklædet}

Islam kan sagtens eksistere uden det islamiske tørklæde, mange muslimer bærer det ikke; men islamismen kan ikke. Men hvorfor og hvordan er det blevet sådan?

Jeg vil først svare med et spørgsmål. Hvorfor indførte mon et regime som det iranske straks fra begyndelsen tørklædetvang? I et land, hvor begge køn plejede at tage til stranden sammen, hvor bikinien og miniskørtet var tilladt. Af hensyn til dyd og moral? Absolut ikke. De iran- ske mullaher har det alt $\mathrm{i}$ alt fint med prostitutionen, og Hashemi Rafsanjani er endog gået så langt som til at anbefale studenter at tage tilflugt til det 'midlertidige ægteskab', som ligner prostitution (manden bestemmer, hvor længe 'ægteskabet' skal vare, ti minutter eller nogle uger, og hvor meget han behøver at betale kvinden).

Tørklædet blev påbudt, og for at sikre at bestemmelsen efterleves, blev der etableret paramilitære militser. Det blev der brugt meget betydelige summer på trods otte års krig og trods en international embargo. Hvorfor? Hvorfor tillægger et islamistisk regime kvindens tørklæde så stor betydning?

Jeg fortsætter med et andet spørgsmål eller snarere en observation. Polygami betragtes som en 'kulturel frihedsrettighed' overalt i den muslimske verden. Men forbudet mod det i de demokratiske vestlige lande har aldrig vakt islamisternes vrede og protester. Hvorfor tog de det mere tungt, da der blev indført tørklædeforbud i skolerne? Og endelig et sidste spørgsmål: Hvorfor er kvinderne i Irak, hvor et islamisk regime er ved at etablere sig, og hvor der er udenlandske soldater, blevet usynlige og tilslørede?

På et semiologisk plan får vi umiddelbart to oplysninger af det islamiske tørklæde på en kvindes hoved: hun er muslim og (den anden og vigtigere oplysning) det er forbudt at 'indtage' hende seksuelt. Det be- 
tyder intet, at tanken ikke havde så meget som strejfet dig. Det er sagt, og det er klart. Som når der er rødt lys: man må ikke passere.

Således reduceres kvinder til deres seksuelle og seksualiserede dimension. Jeg skal ikke her insistere på de nedværdigende og pornografiske sider af dette, som reducerer forholdet mellem mand og kvinde til dyrisk og rå seksualitet og forvandler tørklædet til en slags udfordrende sexslør. Ved at reducere en kvinde til sexobjekt gør tørklædet hende til noget urent, til seksuel lokkemad. Tørklædet definere kvinden som en fare for den islamiske moral, og den tilslørede kvinde bekræfter igen og igen, at de islamiske love er nødvendige, og at de alene kan sikre respekten for de islamiske dogmer. Kvindens tørklæde er det islamistiske systems banner, for så vidt som det ved at vise hvad det skjuler, er en stadig påmindelse om mullahernes orden og lov.

Men det jeg nu vil understrege for at prøve at besvare spørgsmålene fra før, er noget andet. Alle samfund fra de mest primitive til de mest moderne er organiseret omkring udvekslingen af goder. Kvinden er det vigtigste gode, den muslimske mand ejer. Han har juridisk ret til at overvåge hende. Men når den tilslørede pige er kommet på markedet, kan hun kun erhverves af en muslimsk mand. Systemet er ikke fuldkommen lukket; det tillader mænd og kvinder at konvertere til islam og forfølger endog aktivt missionerende dette mål. Men det er ideologisk totalitært, fordi det eliminerer de vantro, ikke-muslimerne.

Når man giver kvinderne tørklæde på, stiller man ikke blot sexmarkedet til skue, men det system, som omslutter det. "Her er de kvinder, som vi har, og som I kun kan få, hvis I konverterer til Islam." Det er de muslimske mænds melding til alle andre mænd. Når man giver kvinderne tørklæde på, udbreder man det syn på verden, på samfundet, på manden og på kvinden, som det islamiske tørklæde sammenfatter, og som kvinderne bærer på hovedet. Det er ikke sikkert, at dette verdenssyn er Koranens. Men det er i hvert fald sikkert, at islamisternes hensigt om at sikre sig enekontrol med et sexmarked ved at mærke de muslimske kvinder strider lodret mod menneskerettighederne og vestlig lov.

Udbredelsen af tørklædet er et helt konkret udtryk for det islamiske systems fremgang, og det islamiske system har brug for tørklædet for at eksistere. Selve dets fundament er baseret på 'det erotiserede despoti', som altid har hersket i islams lande, og som Montesquieu allerede for tre hundrede år siden har beskrevet bedre end nogen i sine Persiske breve, en tveægget satire vendt mod både det attende århundredes franske samfund og de islamiske tyrannier i Orienten.

Jeg vil gerne tilføje, at min antropologiske analyse af det islamiske 


\section{CHAHDORTT DJAVANN}

tørklæde og det islamistiske system hverken er blevet anfægtet af nogen islamolog eller af nogen islamisk dignitar.

Det islamiske tørklæde er ikke et religiøst symbol, det er ikke et symbol på troen, det er ikke et symbol på, at kvinderne underkaster sig Gud, men slet og ret et symbol på kvindernes underkastelse under mændene.

Livet igennem forbliver kvinden en evig mindreårig under formynderskab af en mand i sin familie, som har juridisk ret til at føre opsyn med hende. Det islamiske tørklæde er den kvindelige tilværelses gule jødestjerne. Jeg respekterer mindet om jødeforfølgelserne og ønsker på ingen måde at formindske nazismens forbrydelser. Jeg vil bare med denne sammenligning sige, at tørklædet er et symbol, der udstiller kvinden som retsløs, et undermenneske, som det er tilladt og legitimt at udsætte for enhver form for vold, fordi hun tilhører et mindreværdigt og urent køn. Fundamentalister, som tilslører kvinder, fordi de er urene, udbreder desuden antisemitisme, fordi de også anser jøder som urene væsener, som islams lande må skille sig af med.

I de senere år har islamister, i nogle tilfælde kamufleret som islamologer eller sociologer, anbefalet tørklædet i Vesten for at muslimske kvinder kan beskytte sig mod Vestens slappe og dekadente værdier (samme argument har været brugt i visse venstreintellektuelle miljøer i Iran). Det er gamle omkvæd, som man har hørt, hvis man er vokset op i Iran i revolutionens første år. Andre islamister siger, at tørklædet er en religiøs forskrift, en forskrift i Koranen givet af Gud, som skal adlydes ubetinget.

Men pas på! Det er de samme islamister, som i øvrigt siger, at Koranen er Bøgernes Bog, og at de vantro, de kristne og jøderne skal konvertere til islam, at steder, hvor der bor muslimer er islamisk område, og at der inden for islamisk område kun må være muslimer.

Atter andre forklarer os, uden at rødme, at tørklædet bidrager til kvindens frigørelse. Det er netop i ly af tørklædet, siger de snedigt, at iranske kvinder kan gå på universitetet, arbejde i en virksomhed og frigøre sig intellektuelt. Der er således overhovedet ikke tale om, at kvinderne stigmatiseres, og dermed bliver den islamiske republiks totalitære regime er ikke længere rædselsvækkende, men et forbillede, nærmest et ideal.

Endelig er der nogle, som hævder, at kvinder, der bærer tørklæde i Vesten, gør det af egen fri vilje. Der findes selvfølgelig islamistiske kvinder. I Iran ser man dem, indhyllet i sort fra top til tå, standse piger, hvis tørklæde har ladet et par lokker hår komme til syne. Men de kvinder i Vesten, der selv af en eller anden grund vælger tørklædet, bør vide, at de med deres muligvis frie valg bi- 
drager til undertrykkelsen af de mange, mange millioner kvinder, som er underkastet tørklædetvang i de islamiske lande og ikke kan vælge frit.

Den antropologiske analyse finder et klart sammenfald mellem udbredelsen af tørklædet, specielt i Europa, og den accelererende ekspansion af stærkt missionerende islamistiske bevægelser. Og antropologen undrer sig over, at dette sammenfald tilsyneladende overses af mange af dem, der udtaler sig om det islamiske tørklædes betydning.

\section{Demokrati forudsætter sekularisme}

Der har været demonstrationer verden over mod den franske lov, som forbyder, at man bærer religiøse symboler i skolerne. Selv om de måske lignede andre demonstrationer, skilte de sig alligevel ud. Ikke bare fordi deres melding var indirekte, men også ved den dominerende deltagelse af meget aktive mænd, der afleverede den egentlige og helt klare melding: Disse tørklædeklædte piger er vore kvinder, og vi tager os af dem. Meldingen var meget snedigt henvendt til nogle andre end dem, den foregav at være adresseret til. Islamisterne henvendte sig i virkeligheden ikke primært til den franske regering og heller ikke til den vestlige opinion generelt eller de parlamentarikere, som skulle stemme om loven. Islamisterne ville organisere en spektakulær begiven- hed - som den 11. september, men fredelig.

De henvendte sig frem for alt til de muslimer verden over, som islamisterne forsøger at få med på deres ideologi. De viste dem, at politisk islam var aktiv over hele verden og i fremgang i Vesten, og at unge muslimer modtagelige for deres argumenter var velkomne til at slutte op. Disse demonstrationer viste islamistisk missionsvirksomhed i global skala.

Demonstrationerne mod Muhammed-tegningerne var også spektakulære begivenheder, men mere voldelige. Islamisterne mener, at islams love og dogmer skal respekteres, ikke bare i de muslimske lande, men også i de vestlige, fordi der bor muslimer dér. Bag alle disse begivenheder står selvfølgelig Irans islamistiske regime, hvis mål er at udbrede den islamistiske ideologi til hele verden.

Jeg vil slutte med at minde om demokratiet, ligestillingen mellem kønnene og sekularismen, som står mit hjerte nær; for jeg mistede min ungdom i mullahernes land. Demokratiet kommer ikke af sig selv, det skal vindes, og det skal forsvares. I Vesten er det frugten af to hundrede års kamp. I dag er det et tilbud til immigranter, der som voksne har forladt lande med mere eller mindre diktatoriske regimer. Demokratiet skal man gøre sig fortjent til, og det kræver tid, eftertanke og mod, undervisning og pædagogisk indsats 


\section{CHAHDORTT DJAVANN}

at tilegne sig dets værdier. Sekularismen er en demokratisk værdi på tværs af alle trosretninger, individuelle, kollektive, religiøse og ikke-religiøse; for i et sekulært rum kan man forene folk af forskellig tro, det kan man ikke i en moské, en kirke eller en synagoge. Med den mere og mere massive indvandring har befolkningen i ethvert vestligt land nu i sin midte jøder, katolikker, protestanter, muslimer, ateister, agnostikere, buddhister osv., og alene et sekulært samfund kan forhindre konflikter og religionskrige mellem dem.

Sekularismen som national værdi er garant for, at demokratisk lovgivning, menneskerettigheder og ligestilling mellem kønnene har forrang for alle religiøse love og dogmer. Sekularismen er ikke antireligiøs; men den adskiller troen og det offentlige og politiske liv, og den afviser politisk udnyttelse af religiøs tro og religiøse følelser. Den er garant for borgernes ligestilling, og derfor skal den respekteres i det offentlige rum.

Min respekt for demokratiet, kønnenes ligestilling og sekularismen stikker meget dybt. Jeg har som mange andre set og levet med barbariet i et religiøst og politisk despo- ti. Jeg ved, hvad der sker, når en religion reduceres til sine dogmer, og enhver tanke, enhver filosofi, der afviger fra den religiøse doktrin, betragtes som kætteri og fordømmes. Jeg ved, hvad der sker, når et folks religiøse tro og følelser instrumentaliseres politisk. Fordi jeg har kendt islamistisk totalitarisme, som jeg anser for islamistisk fascisme (som med våbenmagt påtvinger et helt samfund sine dogmer), er og bliver jeg tilhænger af friheden til at vælge sin tro - eller ikke-tro - og praktisere den i sit privatliv og de dertil indrettede steder som moskéer, kirker, templer og synagoger.

Men i vort multikulturelle og multireligiøse samfund skal man friholde det offentlige rum for enhver politisk udnyttelse af religion.

\section{Chahdortt Djavann er fransk skønlitte-} rer og politisk forfatter, uddannet som antropolog. Hun voksede op i Iran og kom efter et par studieår i Istanbul til Frankrig som 23-årig. Hendes indflydelsesrige essay "Kast slфret" kom på dansk $i$ december 2006. Denne artikel er baseret på et foredrag i Det Udenrigspolitiske Selskab i forbindelse med udgivelsen og oversat fra fransk af Klaus Carsten Pedersen 